\title{
IMAGING OF HISTOLOGICAL SECTIONS OF THE HUMAN INTESTINE BY MULTIMODAL CARS MICROSCOPE
}

\author{
A. Dementjev ${ }^{\text {a }}$, J. Kiškis ${ }^{\text {a }}$, and E. Žurauskas ${ }^{\text {b,c }}$ \\ ${ }^{a}$ Center for Physical Sciences and Technology, A. Goštauto 11, LT-01108 Vilnius, Lithuania \\ ${ }^{\mathrm{b}}$ Faculty of Medicine, Vilnius University, , M. K. Čiurlionio 21, LT-03101 Vilnius, Lithuania \\ ' Public Institution National Center of Pathology, P. Baublio 5, LT-08406 Vilnius, Lithuania \\ E-mail: andrej@ar.fi.lt
}

Received 18 November 2011; revised 29 March 2012; accepted 20 September 2012

\begin{abstract}
We demonstrate the capabilities of the coherent anti-Stokes Raman scattering (CARS) microscope and its multimodal operation to image a histological section of human intestinal tissue. The imaging of unstained and stained sections using various nonlinear optical contrasts was performed. The CARS configuration of our microscope allows probing which does not require a preliminary staining of tissue saving the treatment time and providing label-free investigation of original matter. Particular attention was paid to visualisation of unstained tissue. CARS images were recorded in the high wave number Raman spectroscopy region and the spectra of the most distinguished features of images are provided and discussed. Additionally, the two photon excitation fluorescence (TPEF) and second harmonic generation (SHG) contrast mechanisms were used for structural visualisation of both unstained and stained sections of human intestinal tissue. Visualisation of a histological section using all contrast mechanisms mentioned above is analysed and discussed. The research is aimed to draw attention to a potential of CARS/nonlinear microscopy in routine healthcare.
\end{abstract}

Keywords: coherent anti-Stokes Raman scattering (CARS) microscopy, nonlinear microscopy, medical imaging, histology

PACS: 42.65.Dr, 87.64.M, 78.47.jh

\section{Introduction}

For many years histological investigation has been one of the main methods in microscopy examining thin sections of biological tissue. Visualising a microscopic structure of tissue is a powerful and widely used tool in biology and medicine. Histology, using various staining dyes, is capable to enhance the contrast of certain structures of interest [1]. However, examination of a stained section provides information about the unnatural tissue because of the fundamental changes in cellular biochemistry caused by staining treatment. Therefore, non-destructive methods in investigation of biological systems are highly desirable if we want to monitor live objects without changes at the biochemical level, including in vivo experimentations to gain information from live cells. The choice of such methods is not wide. For instance, the most popular method in medicine is magnetic resonance imaging or tomography. In optical investigations only a few non-destructive methods not requiring sample preparation are known - infrared spectroscopy and Raman spectroscopy [2-4]. The Raman scattering phenomenon is utilised for visualisation purposes as a contrast mechanism providing information about chemical composition of tissue.

In recent years the methods of nonlinear optical microscopy have been developed enabling to visualise biological structures using various contrast mechanisms. During the last decades the coherent anti-Stokes Raman scattering (CARS) microscopy gained much attention as a very perspective tool in life science, enabling non-destructive, non-invasive and label-free investigations [5]. Advances and possibilities of CARS microscopy and its biomedical 
applications can be found in details in a specialised review [6]. Briefly, CARS microscopy is a label-free technique with contrast based on intrinsic molecule vibrations enabling chemically selective imaging. CARS is orders of magnitude more sensitive than spontaneous Raman. Nonlinear nature of the CARS signal provides a 3D imaging possibility without using confocal microscopy configuration. The anti-Stokes signal is blue-shifted and therefore is free from one-photon fluorescence background. Despite numerous publications dedicated to CARS imaging [7-11], all of them describe different setups of experimental equipment, object of investigation and consider the potential of such technique for molecular composition, metabolism monitoring, diagnosis, etc.

Our task is to contribute to the practical implementation of the CARS technique considering its application in histology. We demonstrate CARS imaging experiments of unstained sections of human intestinal tissue and compare the results with the picture of the section stained with hematoxylin and eosin. Recently Tuer et al. [12] reported visualisations of histological sections stained with hematoxylin and eosin with nonlinear multicontrast laser scanning microscopy giving images using multiphoton fluorescence (MPF), second harmonic (SHG) and third harmonic generation (THG) contrasts, and a potential of multicontrast nonlinear microscopy in cancerous diagnostic at a single cell level is discussed. In our work a contrast based on the intrinsic molecular vibrations provided by the CARS phenomenon was accompanied by imaging provided by other nonlinear contrast mechanisms such as TPEF and SHG. The imaging using all contrast mechanisms mentioned above was performed by the same CARS microscope set-up. The structural features of the human intestinal tissue revealed by each of the contrasts are described and discussed.

\section{Methods and samples}

For imaging experiments a home-made CARS microscope with a simple and compact laser source (EKSPLA Ltd.) was used. The laser source is described in detail elsewhere [13]. Briefly, the laser consists of a picosecond frequency doubled $\mathrm{Nd}: \mathrm{YVO}_{4}$ pump laser with the pulse repetition rate of $1 \mathrm{MHz}$ equipped with a traveling wave optical parametric generator (OPG) which enables prob- ing the $700-4500 \mathrm{~cm}^{-1}$ range of vibration frequencies. In our scheme for CARS implementation a signal radiation from the OPG (6 ps) was coupled with fundamental wavelength $(1064 \mathrm{~nm})$ and used as pump and Stokes excitation beams, respectively. Measurements of the CARS spectra were performed by tuning OPG wavelength and changing filter sets within five different spectral ranges, enabling investigations with the typical detection rate of $5 \mathrm{~cm}^{-1} / \mathrm{s}$. For example the spectrum from 2500 to $3500 \mathrm{~cm}^{-1}$ was recorded during 3 minutes. Both Stokes and pump beams were collinearly combined and directed to an inverted microscope (Olympus IX71). A spatial filter was used to improve the beam profile before directing into the microscope. The excitation light was focused on the sample with an oilimmersion objective (Olympus, Plan Apochrom., $60 \mathrm{X}$, NA 1.42). In the forward detection scheme the CARS light was collected by a long working distance condenser. Long-pass and short-pass filters were used as a blocking tool for spectral separation of the CARS signal. CARS radiation was detected with the avalanche photodiode (SPCM-AQRH-14, Perkin Elmer), which was connected to a multifunctional board PCI 7833R from National Instruments Ltd. A piezo scanning system (Physik Instrumente $\mathrm{GmbH} \& \mathrm{Co}$ ) was used for scanning the sample. The single frame scans of $200 \times 200$ pixels images were obtained with $2 \mathrm{~ms}$ pixel dwell time. Excitation pulse energies from 0.1 to $1 \mathrm{~nJ}$ at the sample for both pump and Stokes beams were used. Scanning control, data processing and laser wavelength detuning were controlled by a computer.

TPEF and SHG signal detection was realised using the forward and epi-detection, respectively, and utilising appropriate band-pass and interference filters.

Tissue samples were embedded in paraffin, and sections of $4 \mu \mathrm{m}$ thickness were cut with the Leica RM2145 microtome. Sections were stained with hematoxylin and eosin according to the ordinary histology practice [14].

\section{Results and discussion}

\subsection{CARS contrast}

In this work we demonstrate the potential of the nonlinear optical microscopy methods in the histological examination of intestinal tissue. Among 
those methods, a label-free approach utilising visualisation via CARS phenomenon is particularly attractive. The CARS image of the unstained histological section of intestinal tissue is depicted in Fig. 1(a). The pump and Stokes powers were 2 and $1 \mathrm{~mW}$, respectively. The image was recorded at $2840 \mathrm{~cm}^{-1}$ vibrational frequency where a resonant signal from $\mathrm{C}-\mathrm{H}$ stretches is expected. Figure $1(\mathrm{~d})$ shows the spectrum measured at the fixed pixel of image where the CARS signal was strong (indicated with an arrow). The spectrum band of the $\mathrm{C}-\mathrm{H}$ stretches contains several peaks at $2820,2840 \mathrm{~cm}^{-1}$ and $2880,2930 \mathrm{~cm}^{-1}$ which were assigned to the $-\mathrm{CH}_{2},-\mathrm{CH}_{3}$ symmetrical, and $-\mathrm{CH}_{2},-\mathrm{CH}_{3}$ asymmetrical stretches, correspondingly. A strong resonance CARS signal in the spectral region of $\mathrm{C}-\mathrm{H}$ vibrations comes from lipid reach structures of an intestinal cell. The membrane structure and nuclear areas of epithelium cells are easily recognisable in the image. Image contrast $(\sim 1: 7)$ is comparable to that obtained for the transmission light image of an $\mathrm{H} \& \mathrm{E}$ labelled sample (Fig. 1(c)). However, epithelium cell nuclei of intestinal are weakly pronounced in the CARS image of the unstained section.
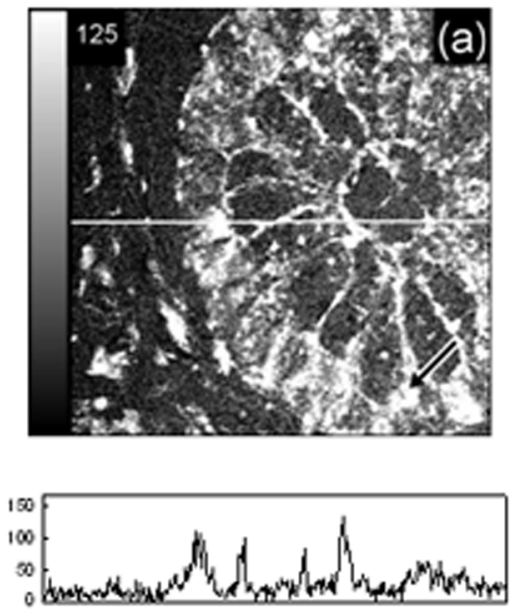
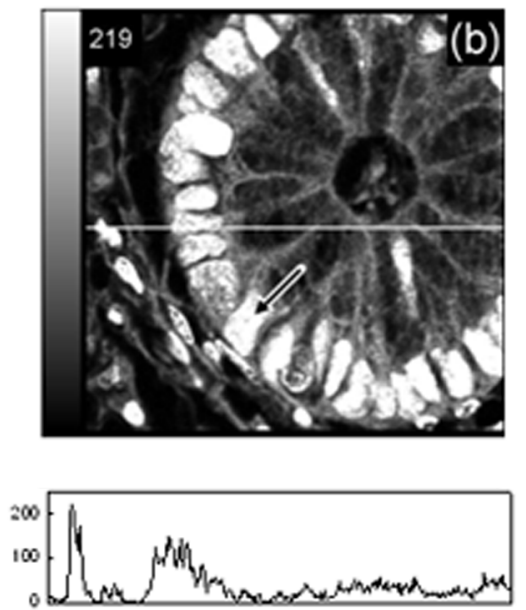
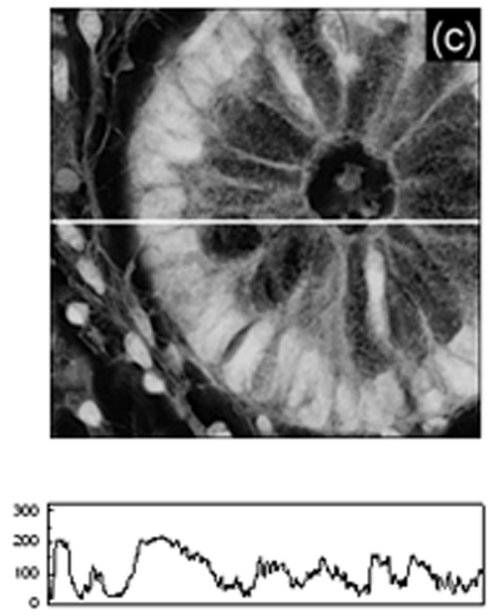
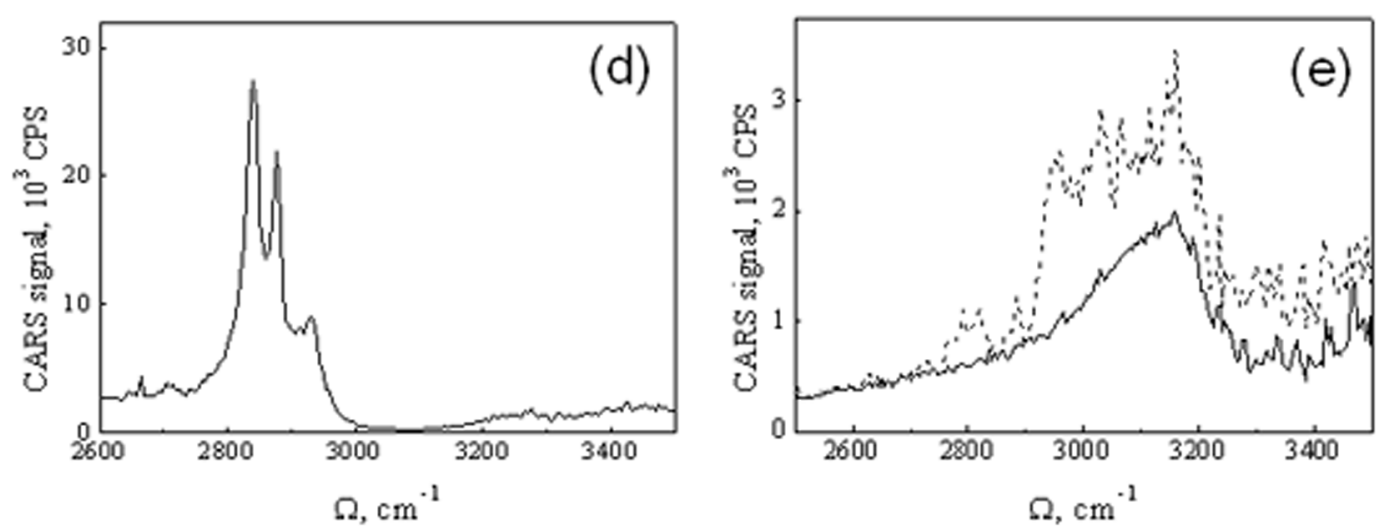

Fig. 1. CARS imaging of human intestinal gland: (a) image of unstained section recorded at $2840 \mathrm{~cm}^{-1}$, the pump and Stokes powers were 2 and $1 \mathrm{~mW}$, respectively; (b) image of $\mathrm{H} \&$ E stained section recorded at $3100 \mathrm{~cm}^{-1}$, the pump and Stokes powers were 0.3 and $0.2 \mathrm{~mW}$, respectively; (c) wide-field transmission image of $\mathrm{H} \& \mathrm{E}$ stained section; (d) and (e) the CARS spectrum obtained at the picture point indicated by the arrow in (a) and (b), respectively. For (a) and (b) images, the appropriate lateral intensity profile along the white line is presented. Picture size $100 \times 100 \mu \mathrm{m}$. Intensity scale bar indicates the number of photons for a single pixel from 0 to the maximal value (the number on top of the bar). For better assessment of the image contrast, the corresponding intensity profiles below each picture are presented. 
In comparison, CARS imaging of a stained histological section was performed. The $\mathrm{i}$ mage of $\mathrm{H} \& \mathrm{E}$ stained tissue (Fig. 1(b)) was recorded at $3100 \mathrm{~cm}^{-1}$ vibrational frequency and showed a very sharp contrast, highlighting the same structural features as can be obtained on the transmission light image of such sample (Fig. 1(c)).

Further, to get spectroscopic information from the $\mathrm{H} \& \mathrm{E}$ stained section we measured the CARS spectrum at the point of the image where the CARS signal was particularly strong. The spectrum contains a wide band centred at $3100 \mathrm{~cm}^{-1}$ (solid line, Fig. 1(e)). We compared this spectrum with the spectrum of hematoxylin solution (dashed line, Fig. 1(d)). The hematoxylin solution has a broad band from 3000 to $3200 \mathrm{~cm}^{-1}$ which should be assigned to the $\mathrm{O}-\mathrm{H}$ stretch of phenol groups of hematoxylin molecule. Thus, in this spectral region the CARS signal originating from an $\mathrm{H} \& \mathrm{E}$ stained sample should be related with hematoxylin dye. Note that the CARS spectrum does not contain C-H stretches which should be expected from a biological compound. At first this result is due to a relatively low excitation power (pump and Stokes powers were 0.3 and $0.2 \mathrm{~mW}$, respectively) not enough to rise the response from biological tissue, but, in turn, sufficient to cause a high response from the dye. Secondary, in the spectral region considered here due to high concentration of the dye one Raman oscillator of the biological molecule corresponds to several oscillators of the dye molecules. Taking into account the quadratic dependence of the CARS signal on the number of oscillators the spectra should contain a distinct features of the dye and vanishing features of the tissue. Thus for the stained section both the CARS spectra and the CARS image represent the dye in the tissue rather than the tissue itself. Imaging at the fixed vibrational frequency within the dye's resonant band gives a very sharp picture bringing out fragments with high concentration of hematoxylin dye: intestinal epithelium cell nuclear as well as lymphocytes localised between intestinal glands. It was verified that recording an image at frequencies outside the hematoxylin resonant band the picture loses a sharp contrast.

The CARS images correlate well with light transmission images of this sample. It should be noted that under experimental conditions when a stained sample is excited by 1064 and $800 \mathrm{~nm}$ wavelengths, corresponding to the $3100 \mathrm{~cm}^{-1}$ Raman shift, the competing process of two photon excitation fluorescence (TPEF) can occur especially due to eosin dye. Nevertheless, the $\mathrm{H} \& \mathrm{E}$ stained section gives an extremely high brightness contrast of about $1: 50$ for a CARS image. In our experiments contribution from TPEF was less than 3\%. For instance, the sample stained only with eosin reveals a very strong signal of two photon excitation fluorescence (data not shown) induced by pump radiation as well as by Stokes radiation in a dual beam scheme of CARS excitation mode. This fact completely eliminates the possibility to record the CARS image from an eosin stained section. Thus, the hematoxylin stained sample is preferred for CARS examination, and eosin staining must be excluded. However, it should be admitted that CARS imaging of a stained section gives minimum additional information in this spectral region and further researches using the CARS contrast mechanism should be directed to the fingerprint spectral region.

\subsection{TPEF contrast}

A further experiment using the TPEF and SHG contrast mechanisms was performed on four histological sections: unstained, stained with eosin or hematoxylin and stained with eosin and hematoxylin. Each section was obtained by serial cutting of the same block of tissue. Figure 2 shows two photon excitation fluorescence images recorded in the spectral range from 550 to $700 \mathrm{~nm}$, while excitation wavelength for all samples was $775 \mathrm{~nm}$. The obtained TPEF image shows that each dye marker distinguishes different structures within intestinal tissue whereas the unstained sample gives a less-structured image. Moreover, the samples have a significantly different intensity of the fluorescence signal. The eosin stained sample gives an image with very intense TPEF up to 344 photons for a single pixel. The TPEF signal from a hematoxylin stained section has intensity from 0 to 25 photons per pixel. The sample stained with $\mathrm{H} \& \mathrm{E}$ dyes reveals even lower TPEF intensity (12 photons per pixel) than for sections stained with either $\mathrm{E}$ or $\mathrm{H}$ dye. Finally, for the sample free of dye (not stained section) the TPEF intensity (18 photons per pixel) is of the order observed for sections stained with hematoxylin or $\mathrm{H} \& \mathrm{E}$ dyes. Thus the fluorescence signal appears depending on the dye type presented in the stained sample or we observe autofluorescence from unstained tissue. The strongest 

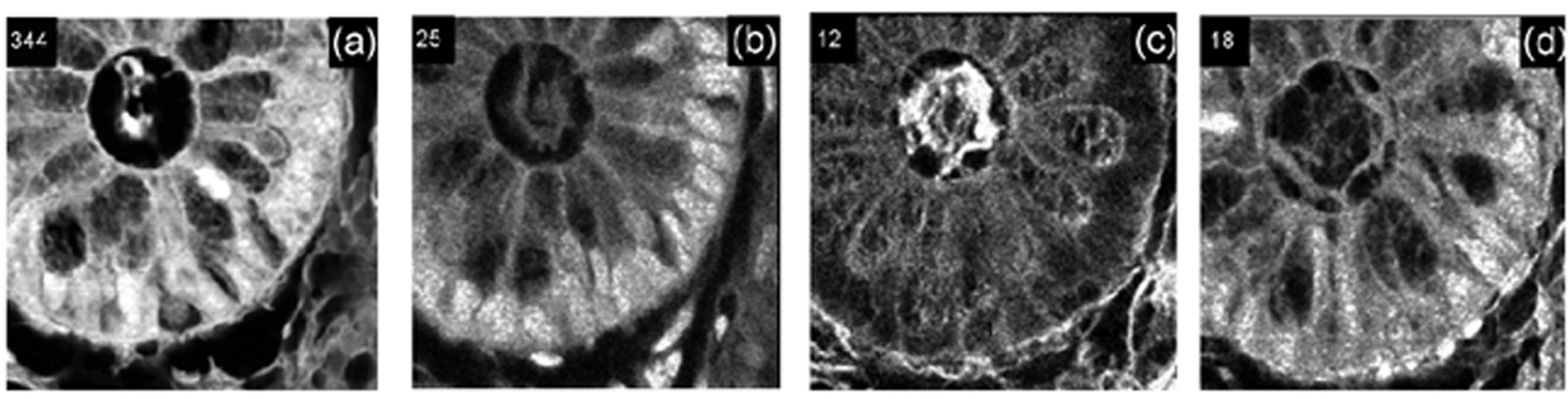

Fig. 2. TPEF images of (a) eosin, (b) hematoxylin, (c) H \& E, and (d) unstained histological sections of human intestinal gland. Picture size $100 \times 100 \mu \mathrm{m}$. Intensity scale bar indicates the number of photons for a single pixel from 0 to the maximal value (the number on top of the bar).

signal was obtained from eosin stained tissue because of a high fluorescence quantum yield of eosin. The TPEF image perfectly identifies a human intestinal gland as a whole giving a very high contrast $(1: 100)$ of the picture. The imaging of the sample stained with hematoxylin dye highlights a nuclear of epithelium cells where hematoxylin couples with chromatin. For this hematoxylin stained section the signal of TPEF was very weak and probably originated from the hemalum complexes characterised by very low nonlinear excitation fluorescence [12]. Nevertheless, the nuclear structure is clearly distinguishable in this case. The sample with the presence of two dyes gives an interesting picture. Although the fluorescence of eosin is strongly quenched by hematoxylin [12] the measurable TPEF is reliably observed to be in the order of ten photons per pixel. Compared to the other samples, $\mathrm{H} \& \mathrm{E}$ stained tissue shows a new structure highlighting the boundaries of epithelium cells. Finally, the autofluorescence from unstained tissue gives a picture showing concentration of organic matter rather than any morphological structure of tissue. Thus, TPEF imaging provides different information about the structure of tissue depending on the dye combination applied for staining.

\subsection{SHG contrast}

At the end of the nonlinear imaging of the human intestinal we recorded images in SHG contrast. In contrast to fluorescence, not all samples show a SHG signal. Only samples stained with eosin or $\mathrm{H} \& \mathrm{E}$ reveal a SHG image (Fig. 3).
An eosin dye stained section gives the second harmonic signal coming from intestinal epithelial cell cytoplasm as well as from nuclear structures, while for the section stained with H\&E only the cytoplasm of intestinal epithelial cells generates the second harmonic. It should be noted that for experimental conditions when excitation was about $1 \mathrm{~nJ}$ per pulse the SHG intensity was very weak and did not exceed 12 and 4 photons per pixel for eosin and $\mathrm{H} \& \mathrm{E}$ samples, respectively. Usually the SHG contrast is used for label-free imaging of ordered cell structures, such as collagen. For our samples no SHG was obtained from the unstained section. SHG occurs only in the presence of the dye in tissue which may indicate about the formation of dye-tissue compound having a non-centrosymmetric structure. This assumption is the subject of study in the future.
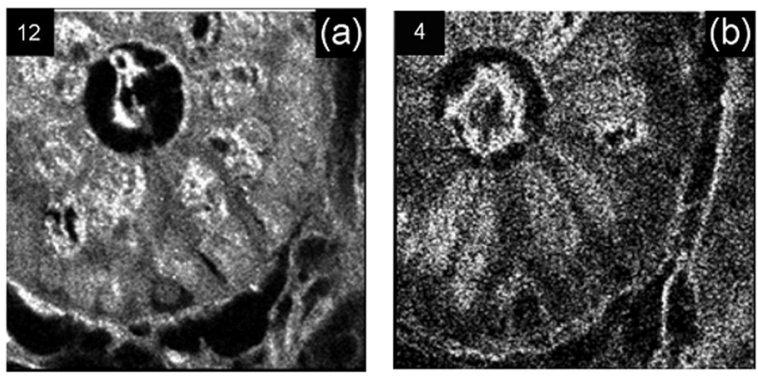

Fig. 3. SHG images of (a) eosin, (b) H \& E stained histological sections of human intestinal gland. Picture size $100 \times 100 \mu \mathrm{m}$. Intensity scale bar indicates the number of photons for a single pixel. 


\section{Conclusion}

In conclusion, we performed the imaging of unstained and hematoxylin and/or eosin stained histological sections of the human intestinal tissue using the multimodal CARS microscope and utilising nonlinear optical contrast mechanisms such as CARS, TPEF and SHG. It was demonstrated that the structure of intestinal tissue can be easily obtained without labelling of a histological section. The image of unstained sections recorded in CARS contrast allows the reliable determining of the intracellular structure of the tissue not worse than that obtained for the $\mathrm{H} \& \mathrm{E}$ stained section with the transmission microscope. The $\mathrm{H} \& \mathrm{E}$ stained section, in turn, gives an extremely high CARS contrast as well, and can be used in histological examination as complementing to the transmission light image. In this work only the $\mathrm{C}-\mathrm{H}$ vibrations region was exploited for CARS imaging. More attractive is the fingerprint region where the most pronounced spectral features of pathological changes in tissue are expected. This is a subject of future investigations.

The current work also demonstrated that the TPEF/SHG imaging of unstained sections or sections stained with different dyes highlights different structural features of the human intestinal tissue. Thus, the alternation of various nonlinear contrasts provided by the CARS microscope and using different dyes for the sample staining allows us to get the images revealing a different morphological structure of the biological tissue. In this context the knowledge about capability of nonlinear microscopy to image biological tissue is important in developing a new approach in microscopic investigations, particularly expanding this technique to the label-free and non-invasive methods in medicine.

\section{Acknowledgments}

The authors thank the National Center of Pathology, Vilnius University Hospital Santariškių Klinikos and its personnel Arvydas Laurinavičius, Romualda Smaliukienè and Justinas Baužys. Thanks to Andrius Devižis for technical assistance.

\section{References}

[1] L.C. Junqueira and J. Carneiro, Basic histology: Text and Atlas (McGraw-Hill, 2005).

[2] B. Schrader, B. Dippel, I. Erb, S. Keller, T. Löchte, H. Schulz, E. Tatsch, and S. Wessel, NIR Raman spectroscopy in medicine and biology: results and aspects, J. Mol. Struct. 480-481, 21-32 (1999).

[3] M. Diem, C. Matthäus, T. Chernenko, M.J. Romeo, M. Miljković, B. Bird, J. Schubert, K. Papamarkakis, and N. Laver, Infrared and Raman spectroscopy and spectral imaging of individual cells, in: Infrared and Raman Spectroscopic Imaging, eds. R. Salzer and H.W. Siezler (WileyVCH Verlag GmbH \& Co., Weinheim, 2009) pp. 173-201.

[4] M.J. Romeo, B. Bird, S. Boydston-White, C. Matthäus, M. Miljković, T. Chernenko, and M. Diem, Infrared and Raman microspectroscopic studies of individual human cells, in: Vibrational Spectroscopy for Medical Diagnosis, eds. M. Diem, J.M. Chalmers, and P.R. Griffiths (John Wiley \& Sons Ltd., Hoboken, 2008) pp. 27-71.

[5] M. Müller and A. Zumbusch, Coherent anti-Stokes Raman scattering microscopy, ChemPhysChem 8, 2156-2170 (2007).

[6] C.L. Evans and X.S. Xie, Coherent anti-Stokes Raman scattering microscopy: chemical imaging for biology and medicine, Annu. Rev. Anal. Chem. 1, 883-909 (2008).

[7] H.A. Rinia, K.N.J. Burder, M. Bonn, and M. Müller, Quantitative label-free imaging of lipid composition and packing of individual cellular lipid droplets using multiplex CARS microscopy, Biophys. J. 95, 4908-4914 (2008).

[8] T.T. Le, T.B. Huff, and J.X. Cheng, Coherent antiStokes Raman scattering imaging of lipids in cancer metastasis, BMC Cancer 9(1), 42 (2009).

[9] H.W. Wang, I.M. Langohr, M. Sturek, and J.-X. Cheng, Imaging and quantitative analysis of atherosclerotic lesions by CARS-based multimodal nonlinear optical microscopy, Arterioscler. Thromb. Vasc. Biol. 29(9), 1342-1348 (2009).

[10] T.T. Le, H.M. Duren, M.N. Slipchenko, C.D. Hu, and J.X. Cheng, Labelfree quantitative analysis of lipid metabolism in living Caenorhabditis elegans, J. Lipid. Res. 51, 672-677 (2010).

[11]S.H. Kim, E.S. Lee, J.Y. Lee, E.S. Lee, B.S. Lee, J.E. Park, and D.W. Moon, Multiplex coherent anti-Stokes Raman spectroscopy images intact atheromatous lesions and concomitantly identifies distinct chemical profiles of atherosclerotic lipids, Circ. Res. 106, 1332-1341 (2010).

[12] A. Tuer, D. Tokarz, N. Prent, R. Cisek, J. Alami, D.J. Dumont, L. Bakueva, J. Rowlands, and V. Barzda, Nonlinear multicontrast microscopy of 
hematoxylin-and-eosin-stained histological section, J. Biomed. Opt. 15(2), 026018 (2010).

[13]A. Dementjev, V. Gulbinas, A. Serbenta, M. Kaucikas, and G. Niaura, Coherent anti-Stokes Raman scattering spectroscope/microscope based on a widely tunable laser source, J. Mod. Opt. 57(6), 503-509 (2010).

[14]J.D. Bancroft and M. Gamble. Theory and Practice of Histological Techniques (Elsevier Health Sciences, 2008).

\title{
ŽMOGAUS ŽARNYNO HISTOLOGINIUU PJŪVIŲ VAIZDINIMAS KOHERENTINĖS ANTISTOKSINĖS RAMANO SKLAIDOS MIKROSKOPU
}

\author{
A. Dementjev ${ }^{a}$, J. Kiškis ${ }^{a}$, E. Žurauskas ${ }^{\text {b, c }}$ \\ ${ }^{a}$ Fiziniu ir technologijos mokslu centro Fizikos institutas, Vilnius, Lietuva \\ ${ }^{\mathrm{b}}$ Vilniaus universiteto Medicinos fakultetas, Vilnius, Lietuva \\ ${ }^{c}$ Valstybinis patologijos centras, Vilnius, Lietuva
}

\section{Santrauka}

Darbe pristatome skenuojančio koherentinès antistoksinės Ramano sklaidos (KARS) mikroskopo galimybes vaizdinti histologinius audinių pjūvius. Pateikiame dažytų ir nedažytų žmogaus žarnyno audinių histologinių pjūviu įvairaus netiesinès optikos kontrasto vaizdus. KARS kontrasto vaizdai leidžia atlikti histologinius tyrimus be bandinio dažymo. Ypatingas dèmesys skirtas nedažyto audinio vaizdinimui. KARS vaizdai registruo- ti didelių Stokso poslinkių srityje. Pateikti ir aptariami ryškiausių struktūrų KARS spektrai. Taip pat pateikti antros harmonikos generacijos bei daugiafotonio žadinimo fluorescencijos vaizdai. Aptarti žmogaus žarnyno audinių dažytų ir nedažytų histologinių pjūvių vaizdai. Tyrimų tikslas - atkreipti dèmesị i KARS mikroskopijos ir netiesinès optinès mikroskopijos potencialą taikant ją iprastos sveikatos priežiūros laboratorinèje praktikoje. 